\title{
Effects of $\mathrm{bpV}$ (pic) and $\mathrm{bpV}$ (phen) on $\mathrm{H9c} 2$ cardiomyoblasts during both hypoxia/reoxygenation and $\mathrm{H}_{2} \mathrm{O}_{2}$-induced injuries
}

\author{
YOUQING TIAN $^{1,2^{*}}$, ABDELKADER DAOUD $^{1 *}$ and JING SHANG ${ }^{1}$ \\ ${ }^{1}$ New Drug Screening Center, China Pharmaceutical University, Nanjing; ${ }^{2}$ Lianyungang TCM Branch, \\ Jiangsu Union Vocational Technical Institute, Lianyungang, Jiangsu, P.R. China
}

Received November 17, 2011; Accepted December 20, 2011

DOI: $10.3892 / \mathrm{mmr} .2011 .737$

\begin{abstract}
Reactive oxygen species (ROS) are involved in myocardial injury. ROS are known to inactivate lipid phosphatase and tension homolog on chromosome 10 (PTEN), an enzyme that increases apoptosis in neonatal cardiomyocytes. $\mathrm{BpV}(\mathrm{pic})$ and $\mathrm{bpV}(\mathrm{phen})$, two bisperoxovanadium molecules and PTEN inhibitors, may be involved in limiting myocardial infarction. To compare the protective effects of $\mathrm{bpV}(\mathrm{pic})$ and $\mathrm{bpV}$ (phen) on ROS-induced cardiomyocyte injury and their possible mechanisms, we selected two popular models of hypoxia/reoxygenation $(\mathrm{H} / \mathrm{R})$ and $\mathrm{H}_{2} \mathrm{O}_{2}$-induced injury in $\mathrm{H} 9 \mathrm{c} 2$ cardiomyoblasts to investigate their effects against injury. We found that pre-treatment with $\mathrm{bpV}($ pic) and $\mathrm{bpV}(\mathrm{phen})$ increased the viability and protected the morphology of $\mathrm{H} 9 \mathrm{c} 2$ cells under the conditions of $\mathrm{H} / \mathrm{R}$ and $\mathrm{H}_{2} \mathrm{O}_{2}$ by inhibiting $\mathrm{LDH}$ release, apoptosis and caspases 3/8/9 activities. However, their respective inhibitory abilities in the two models were different, suggesting that the quantity of ROS from the two models might be different. However, the conflict between ROS and PTEN may affect the action of $\mathrm{bpV}(\mathrm{pic})$ and $\mathrm{bpV}(\mathrm{phen})$. Taken together, the results demonstrate that $\mathrm{bpV}(\mathrm{pic})$ and $\mathrm{bpV}($ phen) have inhibitory effects on oxidative stress-induced cardiomyocyte injury that may be partially modulated by the action of ROS on PTEN.
\end{abstract}

\section{Introduction}

Myocardial ischemia/reperfusion injury (MIRI), which may lead to various complications, including myocardial infarction, cardiac contractile dysfunction and arrhythmia (1-4), has become an increasingly common problem in clinics. However, few strategies directed against MIRI have been tested under clinical conditions $(5,6)$. Recently, a new finding showed

Correspondence to: Dr Jing Shang, New Drug Screening Center, China Pharmaceutical University, 24 Tongjia Road, Nanjing, Jiangsu 210009, P.R. China

E-mail: shangjing2006@yahoo.com.cn

*Contributed equally

Key words: hypoxia/reoxygenation, bpV(pic), bpV(phen), H9c2 cardiomyoblasts, $\mathrm{H}_{2} \mathrm{O}_{2}$, oxidative stress, reactive oxygen species that the pharmacological inhibition of lipid phosphatase and tension homolog on chromosome 10 (PTEN) limited myocardial infarct size and improved left ventricular function post-infarction (7). Moreover, protein tyrosine phosphatase inhibitors and bisperoxovanadium molecules (bpV) inhibited PTEN specifically at low concentrations (8). The protective effects of $\mathrm{bpV}(\mathrm{HOpic})$ on myocardial injury in vitro and in vivo have been observed in previous studies (7). However, other bpV molecules have not been studied and compared for their actions against MIRI.

Based on the cellular mechanisms of ischemia/reperfusion injury that have been extensively explored (9-11), reactive oxygen species (ROS) generated with the re-admission of oxygen are considered the first and main cause of ischemia/ reperfusion injury (12). Thus, scavenging excessive ROS and restoring the reduction-oxidation (redox) balance in the body is an important strategy in inhibiting reperfusion injury, as the redox balance is the solid physiological condition in humans from birth $(13,14)$, and, despite evolution, this balance has always been conserved in all organisms $(15,16)$.

Hydrogen dioxide $\left(\mathrm{H}_{2} \mathrm{O}_{2}\right)$, a famous ROS, inhibits the lipid phosphatase activity of the tumour suppressor PTEN enzyme (17), which suggests that when produced under pathological conditions, such as during MIRI or chronic inflammation, $\mathrm{H}_{2} \mathrm{O}_{2}$ may contribute to the inhibition of apoptosis or necrosis and be involved in cardioprotection. However, a comparative study of this phenomenon in different models of ROS production in cardiomyocytes has not yet been conducted.

In the present study, we selected hypoxia/reoxygenation $(\mathrm{H} / \mathrm{R})$ and $\mathrm{H}_{2} \mathrm{O}_{2}$-induced cardiomyocyte injury models in $\mathrm{H} 9 \mathrm{c} 2$ cardiomyoblasts to investigate and compare the cardioprotective effects of $\mathrm{bpV}(\mathrm{pic})$ and $\mathrm{bpV}(\mathrm{phen})$, two vanadium compounds and PTEN inhibitors (8), and to further discuss the different actions of the two selected models on H9c2 cells (Fig. 1).

\section{Materials and methods}

Reagents. $\mathrm{BpV}(\mathrm{pic})$ and $\mathrm{bpV}(\mathrm{phen})$ were obtained from Enzo Life Sciences Inc. (Farmingdale, NY, USA). H9c2 cardiomyoblasts were purchased from ATCC (Rockville, MD, USA). Dulbecco's modified Eagle's medium (DMEM) and fetal bovine serum (FBS) were purchased from Gibco (Grand Island, NY, USA). Malachite Green reagent, PTEN enzyme and its substrate $\mathrm{PIP}_{3}$ were purchased from Echelon Biosciences Inc. 


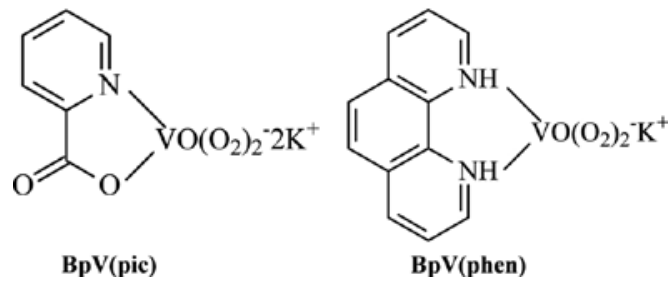

Figure 1. Chemical structures of $\mathrm{bpV}(\mathrm{pic})$ and $\mathrm{bpV}(\mathrm{phen})$.

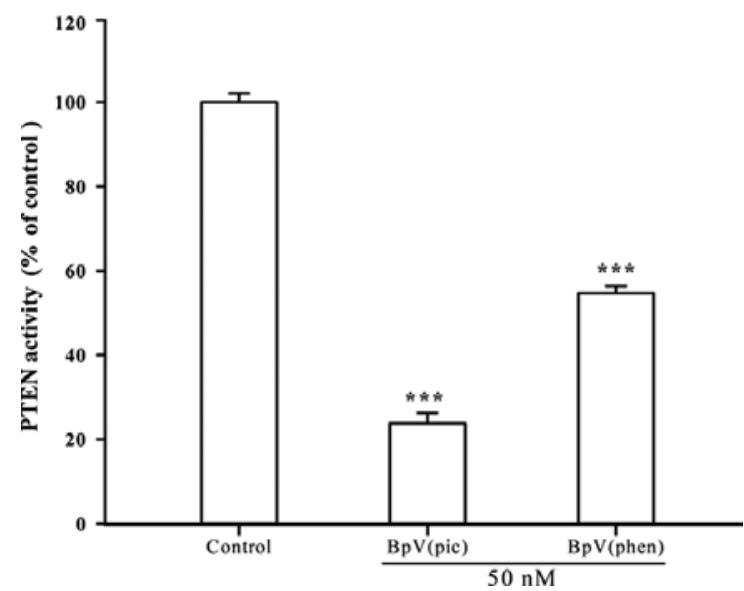

Figure 2. Inhibitory effects of $\mathrm{bpV}(\mathrm{pic})$ and $\mathrm{bpV}(\mathrm{phen})$ on PTEN activity. Recombinant PTEN was pre-incubated with $50 \mathrm{nM}$ of $\mathrm{bpV}$ (pic) or $\mathrm{bpV}($ phen) for $5 \mathrm{~min}$ and then incubated with $3 \mathrm{nM}$ of $\operatorname{PtdIns}(3,4,5) \mathrm{P}_{3}$ for $30 \mathrm{~min}$. PTEN activity was determined by the colorimetric determination of inorganic $\mathrm{H}_{3} \mathrm{PO}_{4}$ levels and shown relative to the activity of uninhibited PTEN (control, $100 \%)$. Data are shown as the means $\pm \mathrm{SD}(\mathrm{n}=5) .{ }^{* * *} \mathrm{P}<0.001$ vs. control.

(Salt Lake City, UT, USA); $\mathrm{H}_{2} \mathrm{O}_{2}$ solution and Trypsin EDTA from Sigma Aldrich (St. Louis, MO, USA); sodium dithionite $\left(\mathrm{Na}_{2} \mathrm{~S}_{2} \mathrm{O}_{4}\right)$ was purchased from SinoPharm Chemical Reagent (Shanghai, China); CCK-8 kit, caspases 3/8/9 kits, Annexin V-FITC kit, lysis buffer and BCA reagent were obtained from Beyotime (Haimen, China); and the lactate dehydrogenase (LDH) kit was obtained from Jiancheng Bioscience (Nanjing, China). Penicillin and streptomycin were purchased from Sunshine Bio (Nanjing, China). Any other chemicals used in this study were of analytical grade.

Cell culture and treatment. $\mathrm{H} 9 \mathrm{c} 2$ cardiomyoblasts were cultured in 100-mm dishes in DMEM containing $4 \mathrm{mM}$ glutamine, $1.5 \mathrm{~g} / 1$ sodium bicarbonate, $4.5 \mathrm{~g} / 1$ glucose, $1.0 \mathrm{mM}$ sodium pyruvate, $12 \%$ (vol/vol) FBS, $100 \mathrm{U} / \mathrm{ml}$ penicillin and $100 \mathrm{U} / \mathrm{ml}$ streptomycin. Cells were incubated at $37^{\circ} \mathrm{C}$ in a humidified atmosphere containing $95 \%$ air, $5 \% \mathrm{CO}_{2}$. Following trypsinization and washing, cells were seeded in 96-well plates ( $4 \times 10^{3}$ cells/well) or 60 -mm dishes $\left(3 \times 10^{5}\right.$ cells/dish). At $\sim 60 \%$ confluence, cells were treated with different concentrations of $\mathrm{bpV}$ (pic) or bpV(phen) in DMEMcontaining 12\% (vol/vol)FBS for $24 \mathrm{~h}$. For the $\mathrm{H} / \mathrm{R}$ model, the medium was replaced with serum-free medium containing $4 \mathrm{mM}$ of $\mathrm{Na}_{2} \mathrm{~S}_{2} \mathrm{O}_{4}$. Following $4 \mathrm{~h}$ of incubation, the medium was again replaced with fresh medium containing $12 \%$ (vol/ $/ \mathrm{vol})$ FBS. In the second part of the experiments, aimed at assessing the contribution of $\mathrm{bpV}(\mathrm{pic})$ and $\mathrm{bpV}\left(\right.$ phen) to the protection against $\mathrm{H}_{2} \mathrm{O}_{2}$-induced cell injury, the medium was supplemented with $50 \mu \mathrm{M}$ of $\mathrm{H}_{2} \mathrm{O}_{2}$.

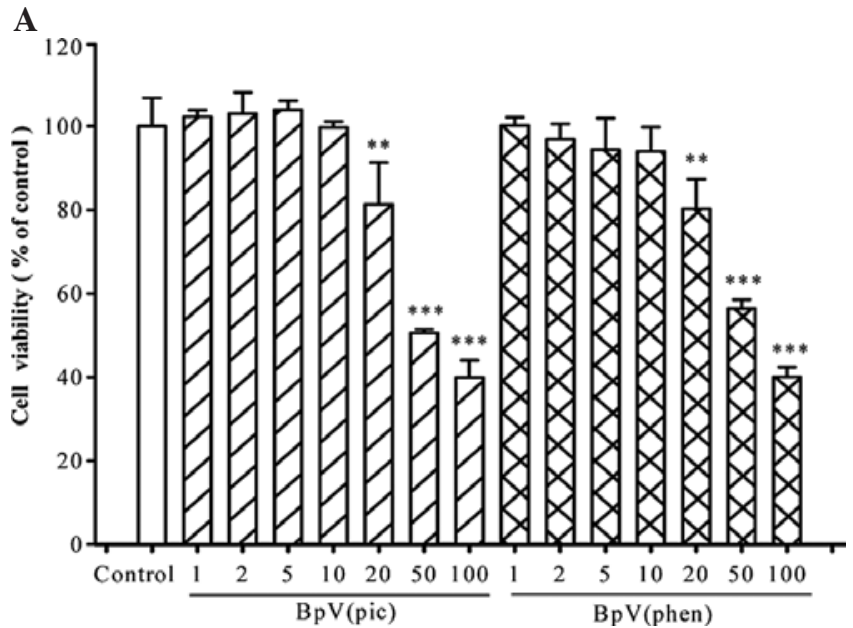

$\mathbf{B}$
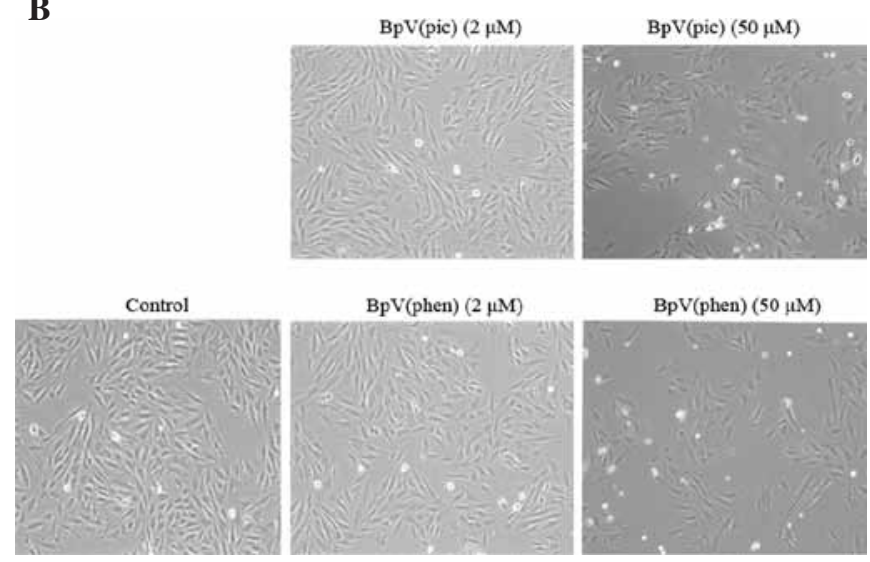

Figure 3. Effects of $\mathrm{bpV}(\mathrm{pic})$ and $\mathrm{bpV}(\mathrm{phen})$ on the viability and morphology of H9c2 cardiomyoblasts. Cells were incubated with PBS (control) or with different concentrations of $\mathrm{bpV}$ (pic) and $\mathrm{bpV}$ (phen) for $24 \mathrm{~h}$. (A) Cell viability, assessed by the CCK-8 assay, was expressed as a percentage of the control, and calculated as: OD treated/OD control x 100. Data are shown as the means $\pm \mathrm{SD}(\mathrm{n}=5) .{ }^{* *} \mathrm{P}<0.01$ and ${ }^{* * *} \mathrm{P}<0.001$ vs. control. (B) Morphological changes were observed under an Olympus inverted microscope (magnification, $\mathrm{x} 100$ ).

Cell viability and morphology analysis were conducted after 4 or $24 \mathrm{~h}$. Control cells were always incubated in DMEM containing $12 \%$ (vol/vol) FBS and model group cells were not treated with $\mathrm{bpV}(\mathrm{pic})$ or $\mathrm{bpV}(\mathrm{phen})$. Cell viability was determined using the colorimetric procedure based on the reduction of a water-soluble tetrazolium salt, 3-(4,5-dimethylthiazol2-yl)-2,5-diphenyltetrazolium bromide (MTT) or CCK-8 using a microplate reader (BioRad, Hercules, CA, USA). H9c2 cell morphology was observed with an inverted microscope (Olympus IX-71, Tokyo, Japan).

Determination of PTEN activity. Recombinant PTEN (rPTEN) activity was determined as follows: $2 \mu \mathrm{g}$ of rPTEN was incubated initially for $5 \mathrm{~min}$ at $37^{\circ} \mathrm{C}$ with $50 \mathrm{nM}$ of bpV(pic) or $\mathrm{bpV}$ (phen) and then for $30 \mathrm{~min}$ with $3 \mathrm{nM}$ of $\mathrm{PIP}_{3}$. The reactions were stopped with $80 \%$ (vol/vol) of Malachite Green reagent and the released phosphates were measured $20 \mathrm{~min}$ later by a colorimetric procedure using a microplate reader (Tecan, Zurich, Switzerland) at $625 \mathrm{~nm}$. PTEN activity was determined by free phosphates released and subsequently converted to a percentage of the control reaction. 


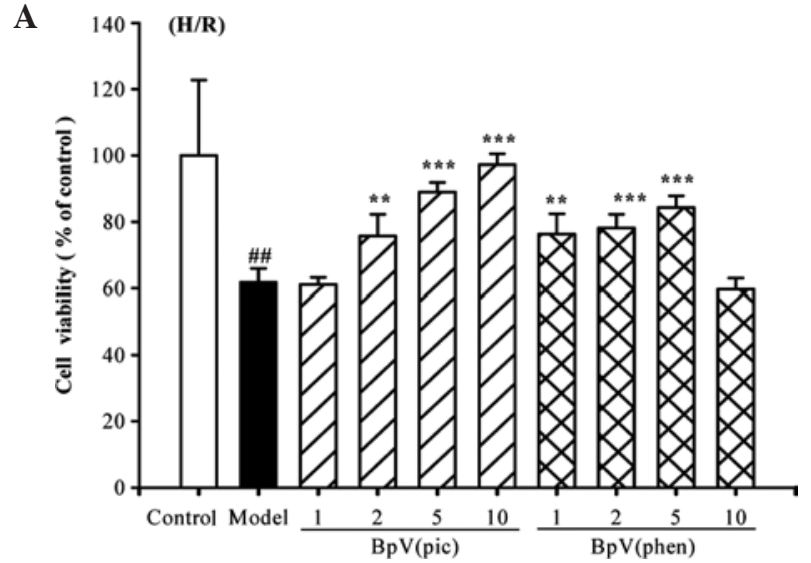

a

C

$(\mathrm{H} / \mathrm{R})$

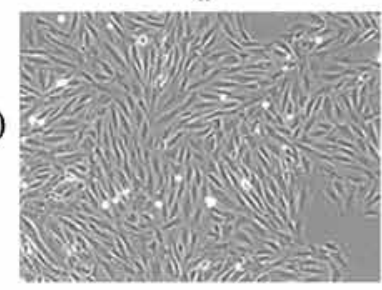

e

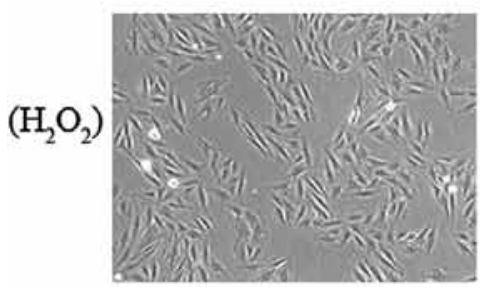

b

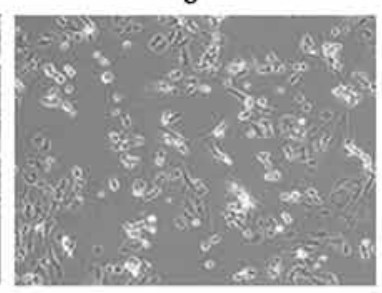

f

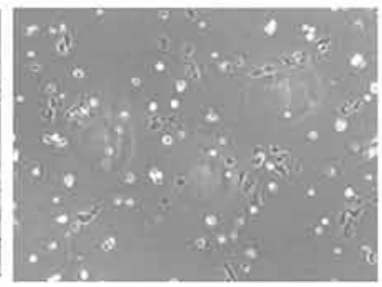

B

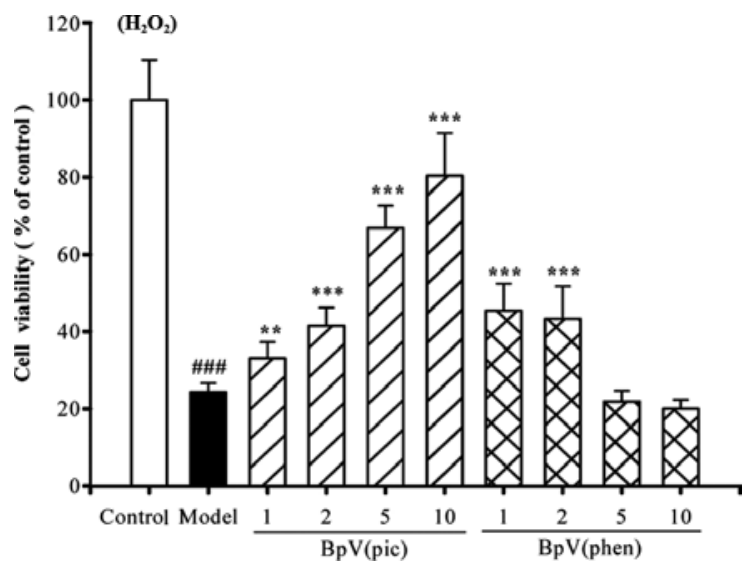

c

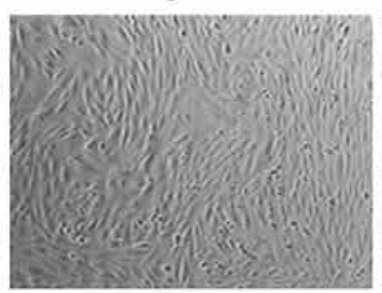

g

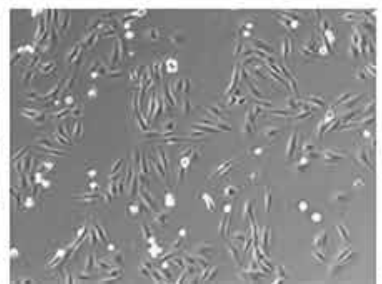

d

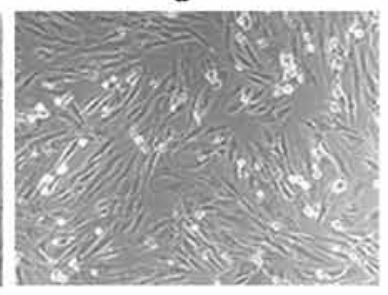

$\mathrm{h}$

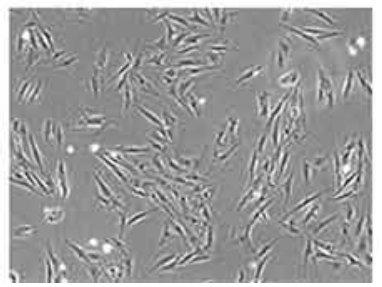

Figure 4. Effects of bpV(pic) and $\mathrm{bpV}$ (phen) on the viability and morphology of $\mathrm{H} 9 \mathrm{c} 2$ cardiomyoblasts during $\mathrm{H} / \mathrm{R}$ and $\mathrm{H}_{2} \mathrm{O}_{2}$ treatment. Cells were incubated with PBS (control) or different concentrations of bpV(pic) and bpV(phen) for $24 \mathrm{~h}$. Cells underwent hypoxia for $1 \mathrm{~h}\left(4 \mathrm{mM} \mathrm{of}^{2} \mathrm{Na}_{2} \mathrm{~S}_{2} \mathrm{O}_{4}\right)$ and reoxygenation for $24 \mathrm{~h}$ or were treated with $50 \mu \mathrm{M}$ of $\mathrm{H}_{2} \mathrm{O}_{2}$ for $4 \mathrm{~h}$. (A and B) Cell viability, assessed by MTT assay, was expressed as a percentage of the control, and calculated as: OD treated/OD control x 100. Data are shown as the means $\pm \mathrm{SD}(\mathrm{n}=5)$. ${ }^{\# \#} \mathrm{P}<0.01$ and ${ }^{\# \# \#} \mathrm{P}<0.001$ vs. control; ${ }^{* * *} \mathrm{P}<0.01$ and ${ }^{* * * *} \mathrm{P}<0.001$ vs. model. (C) Morphological changes were observed under an Olympus inverted microscope (magnification, x100). (a) and (e) control, (b) and (f) model, (c) and (g) cells treated with $2 \mu \mathrm{M}$ of bpV(pic), (d) and (h) cells treated with $2 \mu \mathrm{M}$ of bpV(phen).

Measurement of LDH activity. The activity of LDH in H9c2 cardiomyoblasts released into the medium following treatment with $\mathrm{H} / \mathrm{R}$ or $\mathrm{H}_{2} \mathrm{O}_{2}$ was assessed as previously described (18), i.e., by a spectrophotometric analysis at $440 \mathrm{~nm}$ using an LDH assay kit, according to the manufacturer's instructions.

Flow cytometry. H9c2 cardiomyoblasts were harvested and resuspended in phosphate-buffered saline (PBS) buffer at a concentration of $1 \times 10^{6}$ cells $/ \mathrm{ml}$. Following centrifugation at $1,000 \times \mathrm{g}$ for $5 \mathrm{~min}, 400 \mu 1$ of FITC-conjugated annexin $\mathrm{V}$ binding buffer, $5 \mu \mathrm{l}$ of annexin V-FITC and $5 \mu \mathrm{l}$ of propidium iodide (PI) were added. Following gentle vortexing, the sample was analyzed using a dual-laser FACSCanto flow cytometer (Becton-Dickinson, Mountain View, CA, USA) within a 2-h period. The percentage of apoptotic cells for each sample were estimated.

Caspases 3/8/9 activities assay. H9c2 cardiomyoblasts were lysed with lysis buffer on ice for $15 \mathrm{~min}$ and the lysates were centrifuged $\left(16,000 \mathrm{x}\right.$ g for $15 \mathrm{~min}$ at $\left.4^{\circ} \mathrm{C}\right)$. Subsequently, the protein concentration was determined using the BCA protein assay, and samples $(20 \mu \mathrm{g})$ of the extracted protein were incubated with $100 \mu \mathrm{l}$ of the reaction buffer containing $10 \mu \mathrm{l}$ of caspase substrate (2 mM Ac-DEVD-pNA for caspase 3, Ac-IETD- $p$ NA for caspase 8 and Ac-LEHD- $p$ NA for caspase 9) at $37^{\circ} \mathrm{C}$ for $60-120 \mathrm{~min}$ in a $96-$ well plate. Enzymecatalyzed release of $p$-nitroanilide was measured at $405 \mathrm{~nm}$ using a microplate reader.

Statistical analysis. Data obtained from different experiments were shown as the means \pm SD from at least three independent experiments, and were evaluated by analysis of variance (ANOVA) followed by the Student-Newman-Keuls test. $\mathrm{P}<0.05$ was considered to indicate statistically significant differences.

\section{Results}

Inhibitory effects of $b p V(p i c)$ and $b p V$ (phen) on PTEN activity. To further compare and confirm the inhibitory effects of $\mathrm{bpV}(\mathrm{pic})$ and $\mathrm{bpV}(\mathrm{phen})$ on PTEN activity, and based on a previous study (19), we measured PTEN phosphatase activity in the presence of $\mathrm{bpV}(\mathrm{pic})$ or $\mathrm{bpV}(\mathrm{phen})$ in vitro. Compared 
to the control group, both $\mathrm{bpV}$ (pic) and $\mathrm{bpV}$ (phen) exhibited significant inhibitory effects on PTEN activity (Fig. 2), however, their inhibitions were different; the inhibitory rate of $\mathrm{bpV}$ (pic) was $>70 \%$ (100 to $23.8 \%$ ), while that of $\mathrm{bpV}$ (phen) was $>45 \%$ (100 to $54.7 \%$ ). The inhibitory degrees of these two compounds were in accordance with their $\mathrm{IC}_{50}$ values on PTEN activity, as previously mentioned (19).

Effects of $b p V(p i c)$ and $b p V(p h e n)$ on the viability and morphology of normal H9c2 cardiomyoblasts. To investigate the effects of $\mathrm{bpV}$ (pic) and $\mathrm{bpV}$ (phen) on $\mathrm{H} 9 \mathrm{c} 2$ cardiomyoblasts and to obtain a suitable concentration range for subsequent research, the CCK- 8 kit was used to assess the viability of $\mathrm{H} 9 \mathrm{c} 2$ cardiomyoblasts following treatment with different concentrations of $\mathrm{bpV}(\mathrm{pic})$ and $\mathrm{bpV}($ phen) (1-100 $\mu \mathrm{M})$ for $24 \mathrm{~h}$. The results showed that $\mathrm{bpV}$ (pic) and $\mathrm{bpV}$ (phen) did not cause any decrease in cell viability with concentrations ranging from 1 to $10 \mu \mathrm{M}$. However, compared to the control group, the viability of cells decreased significantly in a concentration-dependent manner from 20 to $100 \mu \mathrm{M}$ (Fig. 3A). Moreover, morphological changes were not evident at a low concentration $(\leq 10 \mu \mathrm{M})$ of these two compounds, but at a higher concentration $(\geq 50 \mu \mathrm{M}), \mathrm{H} 9 \mathrm{c} 2$ cell growth was inhibited (Fig. 3B). Thus, a concentration range of 1 to $10 \mu \mathrm{M}$ of $\mathrm{bpV}$ (pic) and $\mathrm{bpV}$ (phen) was used for the subsequent investigation.

Effects of $b p V(p i c)$ and $b p V(p h e n)$ on the viability and morphology of $\mathrm{H} 9 \mathrm{c} 2$ cardiomyoblasts during $\mathrm{H} / \mathrm{R}$ and $\mathrm{H}_{2} \mathrm{O}_{2}$ treatment. To investigate and compare the protective effects of $\mathrm{bpV}$ (pic) and $\mathrm{bpV}$ (phen) on ROS-induced injury in the two models, MTT assay was used to measure the viability of $\mathrm{H} 9 \mathrm{c} 2$ cardiomyoblasts during $\mathrm{H} / \mathrm{R}$ and $\mathrm{H}_{2} \mathrm{O}_{2}$ treatment following pre-treatment with different concentrations of $\mathrm{bpV}(\mathrm{pic})$ and $\mathrm{bpV}$ (phen) $(1-10 \mu \mathrm{M})$ for $24 \mathrm{~h}$. The data showed that cell viability in the $H / R$ model dropped significantly compared to the control group, and cells treated with $\mathrm{bpV}(\mathrm{pic})(2-10 \mu \mathrm{M})$ or $\mathrm{bpV}$ (phen) (1-5 $\mu \mathrm{M})$ showed a significantly high viability compared to the model group (Fig. 4A). However, there was a more notable decrease in viability in the $\mathrm{H}_{2} \mathrm{O}_{2}$ group compared to the $\mathrm{H} / \mathrm{R}$ group, and cells treated with $\mathrm{bpV}(\mathrm{pic})(1-10 \mu \mathrm{M})$ or $\mathrm{bpV}$ (phen) (1-2 $\mu \mathrm{M})$ showed a better viability compared to the model group (Fig. 4B). Moreover, the mortality of H9c2 cardiomyoblasts caused by $\mathrm{H} / \mathrm{R}$ was evident under the inverted microscope compared to the control group. At the concentration of $2 \mu \mathrm{M}$, both $\mathrm{bpV}$ (pic) and $\mathrm{bpV}$ (phen) protected cells against injury (Fig. 4C). $\mathrm{H}_{2} \mathrm{O}_{2}$-induced cell injury was more severe compared to that caused by $\mathrm{H} / \mathrm{R}$, and again at $2 \mu \mathrm{M}$, $\mathrm{bpV}$ (pic) and $\mathrm{bpV}$ (phen) protected cells against injury.

Effects of $b p V($ pic) and $b p V(p h e n)$ on $\mathrm{LDH}$ release in $\mathrm{H} 9 \mathrm{c} 2$ cardiomyoblasts during $\mathrm{H} / \mathrm{R}$ and $\mathrm{H}_{2} \mathrm{O}_{2}$ treatment. To further evaluate the protective effects of $\mathrm{bpV}$ (pic) and $\mathrm{bpV}$ (phen) in $\mathrm{H} / \mathrm{R}$ and $\mathrm{H}_{2} \mathrm{O}_{2}$ models, we measured $\mathrm{LDH}$ release as an indicator for necrotic cell death (20). $\mathrm{LDH}$ release from $\mathrm{H} 9 \mathrm{c} 2$ cardiomyoblasts in $\mathrm{H} / \mathrm{R}$ and $\mathrm{H}_{2} \mathrm{O}_{2}$ models was increased up to approximately $142.7 \pm 18.1$ and $156.3 \pm 6.7 \%$, respectively, compared to that in the control group (Fig. 5). H/R-induced cell death was inhibited by pre-treatment with $2 \mu \mathrm{M}$ of $\mathrm{bpV}($ pic) $(61.4 \pm 5.1 \%)$ or $\mathrm{bpV}$ (phen) $(70.3 \pm 7.7 \%)$ for $24 \mathrm{~h}$ (Fig. 5A).
A

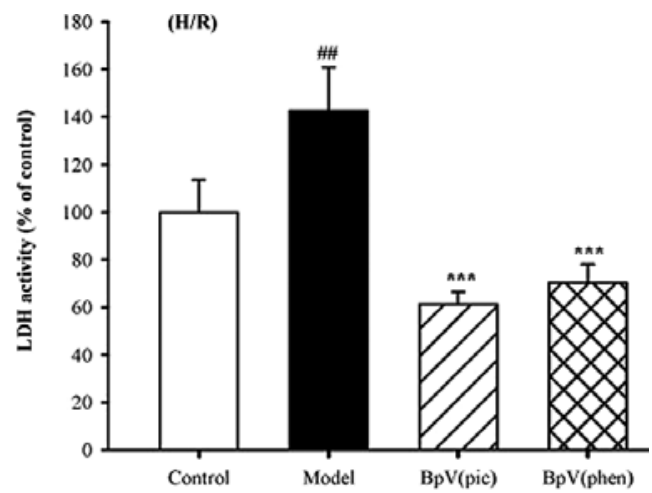

B

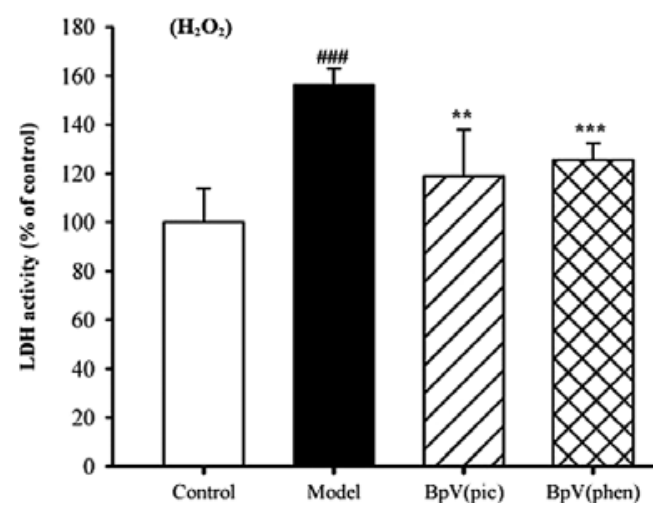

Figure 5. Effects of $\mathrm{bpV}(\mathrm{pic})$ and $\mathrm{bpV}($ phen) on $\mathrm{LDH}$ release in $\mathrm{H} 9 \mathrm{c} 2$ cardiomyoblasts during $\mathrm{H} / \mathrm{R}$ and $\mathrm{H}_{2} \mathrm{O}_{2}$ treatment. Cells were incubated with PBS (control), $2 \mu \mathrm{M}$ of $\mathrm{bpV}$ (pic) or $\mathrm{bpV}$ (phen) for $24 \mathrm{~h}$. (A) Cells underwent hypoxia ( $4 \mathrm{mM}$ of $\mathrm{Na}_{2} \mathrm{~S}_{2} \mathrm{O}_{4}$ ) for $1 \mathrm{~h}$ and reoxygenation for $24 \mathrm{~h}$ or (B) were treated with $50 \mu \mathrm{M}$ of $\mathrm{H}_{2} \mathrm{O}_{2}$ for $4 \mathrm{~h}$. LDH release, assessed by LDH activity assay, was expressed as a percentage of the control, and calculated as: LDH activity treated/LDH activity of control $x 100$. Data are shown as the means $\pm \mathrm{SD}(\mathrm{n}=5) .{ }^{\# \#} \mathrm{P}<0.01$ and ${ }^{\# \# \#} \mathrm{P}<0.001$ vs. control; ${ }^{* *} \mathrm{P}<0.01$ and ${ }^{* * * * *} \mathrm{P}<0.001$ vs. model.

Moreover, $\mathrm{H}_{2} \mathrm{O}_{2}$-induced cell death was inhibited by pretreatment with $2 \mu \mathrm{M}$ of $\mathrm{bpV}$ (pic) $(118.9 \pm 19.0 \%)$ or $\mathrm{bpV}$ (phen) (125.5 $\pm 6.8 \%$ ) for $24 \mathrm{~h}$ (Fig. 5B).

Effects of $b p V($ pic) and $b p V(p h e n)$ on apoptosis in $\mathrm{H} 9 c 2$ cardiomyoblasts during $\mathrm{H} / \mathrm{R}$ and $\mathrm{H}_{2} \mathrm{O}_{2}$ treatment. To evaluate the anti-apoptotic effects of $\mathrm{bpV}$ (pic) and $\mathrm{bpV}$ (phen) in the $\mathrm{H} / \mathrm{R}$ and $\mathrm{H}_{2} \mathrm{O}_{2}$ models, the apoptotic rate was quantified by flow cytometry. Apoptotic cell levels increased from $4.3 \%$ in the control group to $31.6 \%$ in the $\mathrm{H} / \mathrm{R}$ and $51.8 \%$ in the $\mathrm{H}_{2} \mathrm{O}_{2}$ group (Fig. 6). Pre-treatment with $2 \mu \mathrm{M}$ of bpV(pic) and $\mathrm{bpV}$ (phen) for $24 \mathrm{~h}$ decreased the apoptotic rate in the $\mathrm{H} / \mathrm{R}$ group to 6.3 and $14.4 \%$, respectively, and in the $\mathrm{H}_{2} \mathrm{O}_{2}$ group to 11.6 and $24.8 \%$, respectively (Fig. 6B).

Effects of $b p V(p i c)$ and $b p V($ phen $)$ on caspases 3/8/9 activities in $\mathrm{H} 9 \mathrm{c} 2$ cardiomyoblasts during $\mathrm{H} / \mathrm{R}$ and $\mathrm{H}_{2} \mathrm{O}_{2}$ treatment. To determine the underlying cardioprotective mechanism of $\mathrm{bpV}($ pic $)$ and bpV(phen) on $\mathrm{H} 9 \mathrm{c} 2$ cardiomyoblast injury during $\mathrm{H} / \mathrm{R}$ and $\mathrm{H}_{2} \mathrm{O}_{2}$ treatment, caspases 3/8/9 activities were measured. The results revealed that $\mathrm{bpV}$ (pic) and $\mathrm{bpV}$ (phen) inhibited the increased caspases 3/8/9 activities in the $\mathrm{H} / \mathrm{R}$ and $\mathrm{H}_{2} \mathrm{O}_{2}$ models in $\mathrm{H} 9 \mathrm{c} 2$ cardiomyoblasts (Fig. 7). The data also showed that caspases $3 / 8 / 9$ activities were different in the two models. Caspases $3 / 8$ activities were much higher in $\mathrm{H} 9 \mathrm{c} 2$ cardiomyoblasts treated 
A
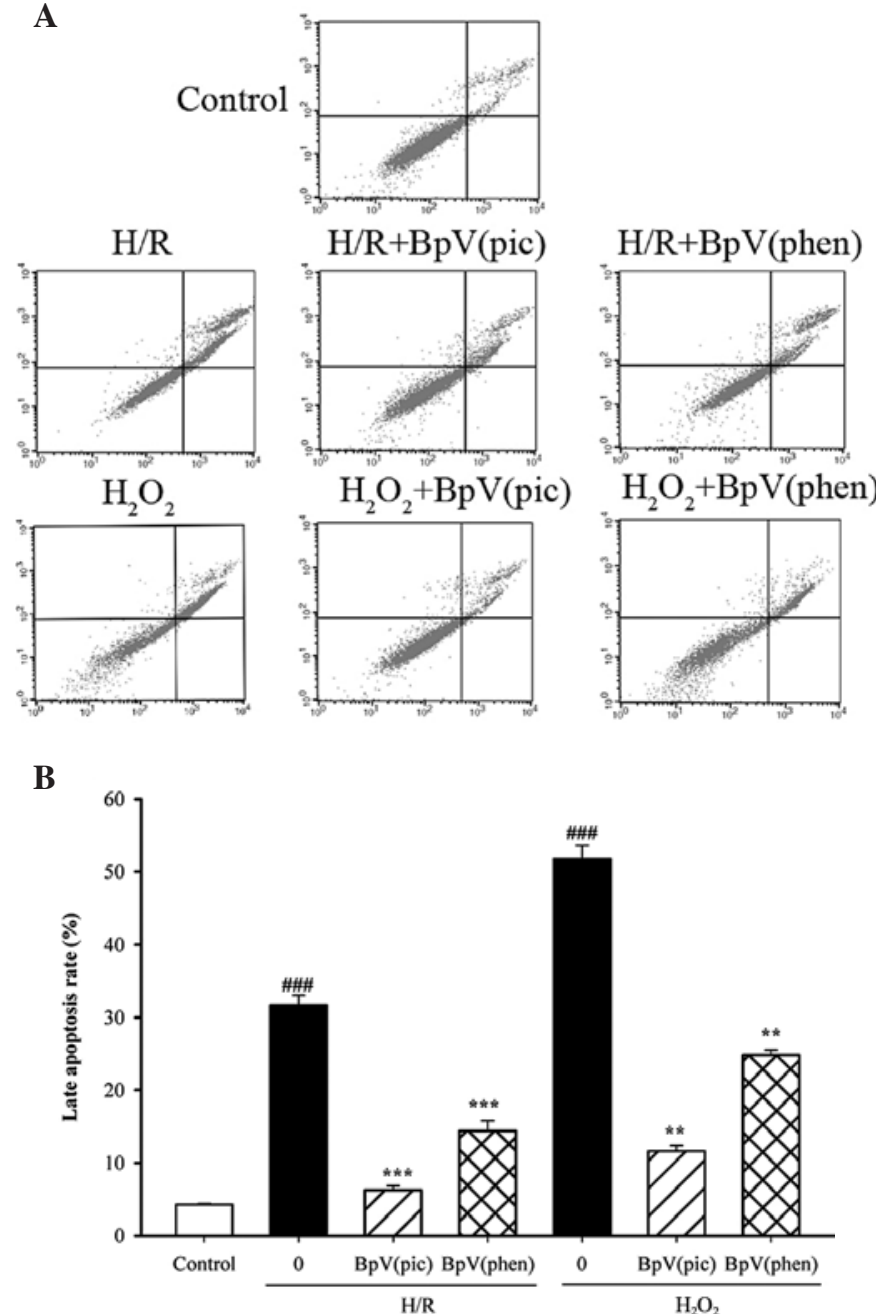

Figure 6. Inhibitory effects of $\mathrm{bpV}(\mathrm{pic})$ and $\mathrm{bpV}(\mathrm{phen})$ on apoptosis in $\mathrm{H} 9 \mathrm{c} 2$ cardiomyoblasts during $\mathrm{H} / \mathrm{R}$ and $\mathrm{H}_{2} \mathrm{O}_{2}$ treatment. Cells were incubated with $2 \mu \mathrm{M}$ of bpV(pic) or bpV(phen) for $24 \mathrm{~h}$ and then underwent hypoxia $(4 \mathrm{mM}$ of $\mathrm{Na}_{2} \mathrm{~S}_{2} \mathrm{O}_{4}$ ) for $1 \mathrm{~h}$ and reoxygenation for $24 \mathrm{~h}$ or were treated with $50 \mu \mathrm{M}$ of $\mathrm{H}_{2} \mathrm{O}_{2}$ for $4 \mathrm{~h}$. After adding Annexin V-FITC/PI, cells were analyzed with FACSCanto flow cytometer. (A) Flow cytometry of $\mathrm{H} / \mathrm{R}$ and $\mathrm{H}_{2} \mathrm{O}_{2-}$ induced apoptosis in $\mathrm{H} 9 \mathrm{c} 2$ cells with or without treatment with $\mathrm{bpV}$ (pic) and $\mathrm{bpV}$ (phen). (B) Quantitative analysis of the apoptotic rate using flow cytometry. Data are shown as the means $\pm \mathrm{SD}(\mathrm{n}=2) .{ }^{\# \#} \mathrm{P}<0.001 \mathrm{vs}$. control; ${ }^{* *} \mathrm{P}<0.01$ and ${ }^{* * *} \mathrm{P}<0.001$ vs. model.

with $\mathrm{H}_{2} \mathrm{O}_{2}$ (308.4 \pm 41.5 and $250.6 \pm 20.7 \%$, respectively) than in those from the H/R group (226.8 \pm 9.8 and $170.5 \pm 17.9 \%$, respectively), whereas caspase 9 activity varied slightly in the two models (146.4 $\pm 23.8 \%$ in $\mathrm{H}_{2} \mathrm{O}_{2}$ and $167.3 \pm 26.5 \%$ in $\mathrm{H} / \mathrm{R}$ ). Finally, the protective effects of $\mathrm{bpV}$ (pic) and $\mathrm{bpV}$ (phen) against the injury in the two models were apparent.

\section{Discussion}

PTEN, a dual protein-lipid phosphatase, is the major downregulator of the pro-oncogenic PI3K/Akt pathway by degrading phosphatidylinositol 3,4,5-trisphosphate $\left(\mathrm{PIP}_{3}\right)$ to an inactive form of phosphatidylinositol 4,5-bisphosphate $\left(\mathrm{PIP}_{2}\right)$, and thus inhibits Akt activation (21-25). Overexpression of PTEN increases apoptosis in neonatal cardiomyocytes, whereas the inhibition of PTEN activates the Akt pro-survival pathway, reduces apoptosis and increases cell survival (8,26-28).

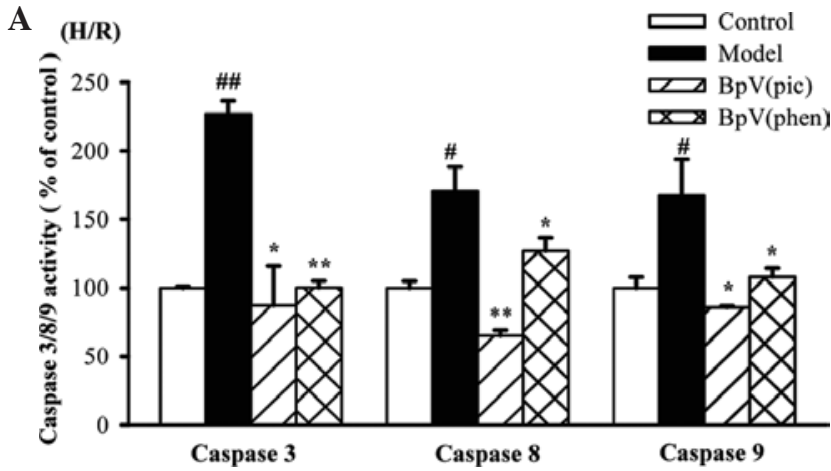

B $\left(\mathrm{H}_{2} \mathrm{O}_{2}\right)$

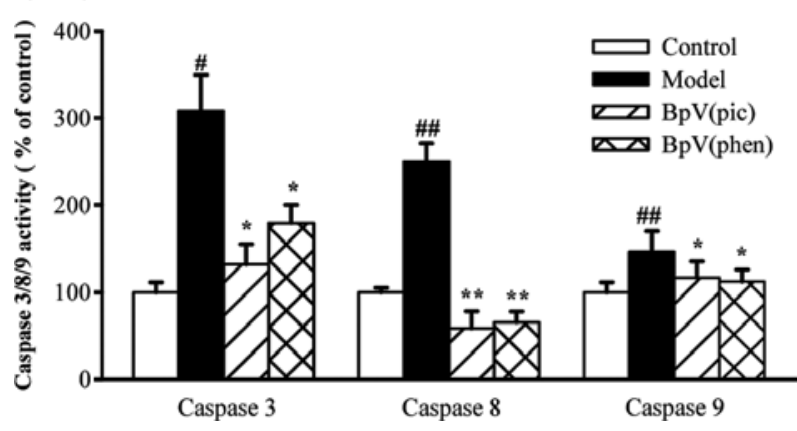

Figure 7. Effects of $\mathrm{bpV}$ (pic) and $\mathrm{bpV}($ phen) on caspases $3 / 8 / 9$ activities in $\mathrm{H} 9 \mathrm{c} 2$ cardiomyoblasts during $\mathrm{H} / \mathrm{R}$ and $\mathrm{H}_{2} \mathrm{O}_{2}$ treatment. Cells were incubated with PBS (control), $2 \mu \mathrm{M}$ of $\mathrm{bpV}$ (pic) or bpV(phen) for $24 \mathrm{~h}$. (A) The cells then underwent hypoxia ( $4 \mathrm{mM}$ of $\mathrm{Na}_{2} \mathrm{~S}_{2} \mathrm{O}_{4}$ ) for $1 \mathrm{~h}$ and reoxygenation for $24 \mathrm{~h}$, or (B) were treated with $50 \mu \mathrm{M}$ of $\mathrm{H}_{2} \mathrm{O}_{2}$ for 4 h. Caspases $3 / 8 / 9$ activities during both injuries were expressed as percentages of the control, and calculated as: caspases 3/8/9 activities treated/caspases 3/8/9 activities of control x 100 Data are shown as the means $\pm \mathrm{SD}(\mathrm{n}=5)$. ${ }^{\#} \mathrm{P}<0.05$ and ${ }^{\# \#} \mathrm{P}<0.01$ vs. control; ${ }^{*} \mathrm{P}<0.05$ and ${ }^{* *} \mathrm{P}<0.01$ vs. model.

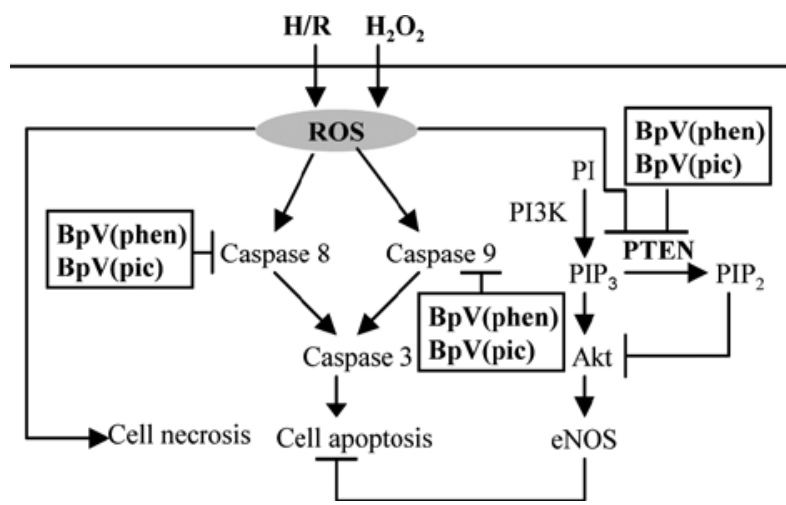

Figure 8. A proposed mechanism for the inhibitory effects of $\mathrm{bpV}(\mathrm{pic})$ and $\mathrm{bpV}$ (phen) on ROS-induced cell apoptosis and necrosis by affecting three pathways. Our data demonstrate that $\mathrm{bpV}$ (pic) and $\mathrm{bpV}$ (phen) attenuate the $\mathrm{H} / \mathrm{R}$ and $\mathrm{H}_{2} \mathrm{O}_{2}$-induced apoptosis and necrosis of $\mathrm{H} 9 \mathrm{c} 2$ cardiomyoblasts, which may be due to the inhibition of the caspases 3/8/9 and PTEN activities. H/R, hypoxia/reoxygenation; ROS, reactive oxygen species; PTEN, lipid phosphatase and tensin homolog on chromosome 10; PI, phosphatidylinositol; $\mathrm{PIP}_{2}$, phosphatidylinositol 4,5-bisphosphate; $\mathrm{PIP}_{3}$, phosphatidylinositol 3,4,5-trisphosphate; PI3K, phosphoinositide 3-kinase; eNOS, endothelial nitric oxide synthase.

Targeting PTEN via pharmacological inhibition may thus provide a new approach for the therapy of MIRI in clinics.

Although there are only a few highly specific PTEN inhibitors, bpV is a relatively specific inhibitor of PTEN (8). 
Furthermore, $\mathrm{bpV}(\mathrm{HO}$ pic $)$ has been shown to attenuate simulated ischemia/reperfusion injury in cardiomyocytes, and to limit myocardial infarct size and ameliorate cardiac dysfuction post-infarct in vivo (7). To further investigate the protective effects of other bpVs on cardiomyocytes, we selected $b p V(p i c)$ and $\mathrm{bpV}$ (phen) from a list of $\mathrm{bpV}$ compounds that have already been tested on PTEN (8).

$\mathrm{H} 9 \mathrm{c} 2$ is a rat-derived cardiomyoblast cell line that exhibits morphological characteristics similar to those of immature embryonic cardiomyocytes, but preserves several elements of the electrical and hormonal signaling pathway found in adult cardiac cells $(29,30)$. H9c2 cardiomyoblasts have been widely used to screen active components $(31,32)$. To investigate the potency of new inhibitors on MIRI, H/R and $\mathrm{H}_{2} \mathrm{O}_{2}$-induced cell injury models are often used in vitro (33-37). Therefore, the two models were also used in our study to evaluate the protective effects of $\mathrm{bpV}$ (pic) and $\mathrm{bpV}$ (phen).

In the present study, exogenous $\mathrm{H}_{2} \mathrm{O}_{2}(50 \mu \mathrm{M})(38,39)$ and oxygen scavenger $\mathrm{Na}_{2} \mathrm{~S}_{2} \mathrm{O}_{4}$ (40) were selected to set up two in vitro chemical models for the study of ROS activity. Based on cell viability, cell morphology, LDH release and the apoptosis assay, we showed that the two in vitro models were different (Figs. 4-6). $\mathrm{H}_{2} \mathrm{O}_{2}$-induced injury in $\mathrm{H} 9 \mathrm{c} 2$ cells was more severe than $\mathrm{H} / \mathrm{R}$ from its impact on cell viability and morphology. Additionally, LDH release and apoptosis results were in accordance with the above results, indicating that the induced necrosis in the $\mathrm{H}_{2} \mathrm{O}_{2}$ model was more significant than that in the H/R model.

Based on the different inhibitory activities of $\mathrm{bpV}(\mathrm{pic})$ and $\mathrm{bpV}$ (phen) on PTEN in vitro and their non-toxic concentration range in $\mathrm{H} 9 \mathrm{c} 2$ cells (Figs. 2 and 3), their individual effects on cell viability and morphology in $\mathrm{H} 9 \mathrm{c} 2$ cells injured during $\mathrm{H} / \mathrm{R}$ or $\mathrm{H}_{2} \mathrm{O}_{2}$ treatment, were studied. Our data reveal that both $\mathrm{bpV}$ (pic) and $\mathrm{bpV}$ (phen) significantly protected $\mathrm{H} 9 \mathrm{c} 2$ cell injury induced in both models, with high activity of $\mathrm{bpV}(\mathrm{pic})$ (Fig. 4). Moreover, the results of LDH release, apoptosis and caspases 3/8/9 activities confirm the above-mentioned data regarding the cardioprotective activities of $\mathrm{bpV}(\mathrm{pic})$ and $\mathrm{bpV}$ (phen) that may be relevant to their inhibitory ability on PTEN activity (Figs. 5-7).

The present findings have shown that $\mathrm{bpV}(\mathrm{pic})$ and $\mathrm{bpV}$ (phen) protect $\mathrm{H} 9 \mathrm{c} 2$ against ROS-induced injury by inhibiting cell necrosis and apoptosis, and thus potentially protect cardiomyocytes against I/R injury. Their mechanisms probably include three pathways: i) the inhibition of caspases 8 and 3 , ii) the inhibition of caspases 9 and 3, and iii) the inhibition of PTEN and the activation of the PI3K/Akt signaling pathway (Fig. 8).

Apoptosis and necrosis are linked to the excess of intracellular ROS production $(41,42) \cdot \mathrm{H}_{2} \mathrm{O}_{2}$, as an important ROS, leads to the formation of hydroxyl radicals $(\mathrm{OH} \cdot)$ mediated by intracellular heavy metal ions through the Fenton reaction. On the other hand, cells subjected to $\mathrm{H} / \mathrm{R}$ may produce a large quantity of $\mathrm{H}_{2} \mathrm{O}_{2}, \mathrm{O}_{2}{ }^{-}, \mathrm{OH} \cdot$ and other $\operatorname{ROS}(43,44)$. All ROS induce severe intracellular oxidative stress, which damages various intracellular biomacro-molecules and eventually results in cell apoptosis and necrosis (45). Moreover, either endogenous $\mathrm{H}_{2} \mathrm{O}_{2}$ or endogenous ROS production inhibit PTEN activity $(17,46)$. Thus, the different effects of $\mathrm{H} / \mathrm{R}$ and $\mathrm{H}_{2} \mathrm{O}_{2}$ on cell viability are not only relevant to the quantity of ROS, but also to the inhibi- tory capacity of ROS on the PTEN enzyme, suggesting that the protective effects of $\mathrm{bpV}$ (pic) and $\mathrm{bpV}$ (phen) against $\mathrm{H}_{2} \mathrm{O}_{2}$ and $\mathrm{H} / \mathrm{R}$-induced injuries in $\mathrm{H} 9 \mathrm{c} 2$ cells are the comprehensive result of actions of the two compounds on the ROS system and PTEN and the action of ROS on PTEN as well.

In the present study, we assessed the protective effects of $\mathrm{bpV}$ (pic) and $\mathrm{bpV}$ (phen) on ROS-induced injury in $\mathrm{H} 9 \mathrm{c} 2$ cardiomyocytes. We also compared the different actions of the two ROS models and discussed the synergetic action of ROS and PTEN inhibitors through the PTEN enzyme, which is likely to be useful in preventing MIRI. Nevertheless, more studies are required to explore ROS balance and its role in health and injury.

\section{Acknowledgements}

This study was supported by a grant from the Major Scientific and Technological Specialized Project for 'New Drugs Development' (No. 2009ZX09401-007).

\section{References}

1. Wang $\mathrm{J}$ and Li J: Activated protein $\mathrm{C}$ : a potential cardioprotective factor against ischemic injury during ischemia/reperfusion. Am J Transl Res 1: 381-392, 2009.

2. Jennings RB, Sommers HM, Smyth GA, Flack HA and Linn H: Myocardial necrosis induced by temporary occlusion of a coronary artery in the dog. Arch Pathol 70: 68-78, 1960.

3. Braunwald E and Kloner RA: Myocardial reperfusion: a doubleedged sword? J Clin Invest 76: 1713-1719, 1985.

4. Derek MY, D Sc and Derek JH: Myocardial reperfusion injury. New Engl J Med 357: 1121-1135, 2007.

5. The EMIP-FR Group: Effect of 48-h intravenous trimetazidine on short- and long-term outcomes of patients with acute myocardial infarction, with and without thrombolytic therapy; A double-blind, placebo-controlled, randomized trial. Eur Heart J 21: $1537-1546,2000$

6. Marzilli M and Huqi A: Cardioprotective therapy in reperfusion injury: lessons from the European Myocardial Infarction ProjectFree Radicals (EMIP-FR). Heart Metab 46: 35-37, 2010.

7. Keyes KT,Xu J,Long B,Zhang C,HuZ and Ye Y: Pharmacological inhibition of PTEN limits myocardial infarct size and improves left ventricular function postinfarction. Am J Physiol Heart Circ Physiol 298: H1198-H1208, 2010.

8. Schmid AC, Byrne RD, Vilar R and Woscholski R: Bisperoxovanadium compounds are potent PTEN inhibitors. FEBS Lett 566: 35-38, 2004.

9. Fliss H and Gattinger D: Apoptosis in ischemic and reperfused rat myocardium. Circ Res 79: 949-956, 1996.

10. Chakrabarti S, Hoque AN and Karmazyn M: A rapid ischemiainduced apoptosis in isolated rat hearts and its attenuation by the sodium-hydrogen exchange inhibitor HOE 642 (cariporide). J Mol Cell Cardiol 29: 3169-3174, 1997.

11. Maulik N, Yoshida T and Das DK: Regulation of cardiomyocyte apoptosis in ischemic reperfused mouse heart by glutathione peroxidase. Mol Cell Biochem 196: 13-21, 1999.

12. Fantini E, Demaison L, Sentex E, Grynberg A and Athias P: Some biochemical aspects of the protective effect of trimetazidine on rat cardiomyocytes during hypoxia and reoxygenation. J Mol Cell Cardiol 26: 949-958, 1994.

13. Signorini C, Perrone S, Sgherri C, et al: Plasma esterified F2-isoprostanes and oxidative stress in newborns: role of nonprotein-bound iron. Pediatr Res 63: 287-291, 2008.

14. Maron JL, Johnson KL, Parkin C, Iyer L, Davis JM and Bianchi DW: Cord blood genomic analysis highlights the role of redox balance. Free Radic Biol Med 49: 992-996, 2010.

15. David F: Biogeochemistry: Earth's redox evolution. Nat Geosci 3: 453-454, 2010.

16. Sagemark J, Elgán TH, Bürglin TR, Johansson C, Holmgren A and Berndt KD: Redox properties and evolution of human glutaredoxins. Proteins 68: 879-892, 2007.

17. Lee SR, Yang KS, Kwon J, et al: Reversible inactivation of the tumor suppressor PTEN by $\mathrm{H}_{2} \mathrm{O}_{2}$. J Biol Chem 277: 20336-20342, 2002. 
18. Moon CH, Jung YS, Kim MH, Park RM, Lee SH and Baik EJ: Protein kinase $\mathrm{C}$ inhibitors attenuate protective effect of high glucose against hypoxic injury in $\mathrm{H} 9 \mathrm{c} 2$ cardiac cells. Jpn J Physiol 50: 645-649, 2000

19. Halliwell B and Gutteridge JMC: The chemistry of oxygen radicals and other oxygen-derived species. Free Radic Biol Med: 20-64, 1985

20. Filipovic DM, Meng X and Reeves WB: Inhibition of PARP prevents oxidant-induced necrosis but not apoptosis in LLC-PK1 cells. Am J Physiol 277: F428-F436, 1999.

21. Lee JO, Yang H, Georgescu MM, et al: Crystal structure of the PTEN tumor suppressor: implications for its phosphoinositide phosphatase activity and membrane association. Cell 99: 323-334, 1999.

22. Maehama T and Dixon JE: The tumor suppressor, PTEN/ MMAC1, dephosphorylates the lipid second messenger, phosphatidylinositol 3,4,5-trisphosphate. J Biol Chem 273: 13375-13378, 1998.

23. Oudit GY, Sun H, Kerfant BG, Crackower MA, Penninger JM and Backx PH: The role of phosphoinositide-3 kinase and PTEN in cardiovascular physiology and disease. J Mol Cell Cardiol 37: 449-471, 2004

24. Stambolic V, Suzuki A, de la Pompa JL, et al: Negative regulation of PKB/Akt-dependent cell survival by the tumor suppressor PTEN. Cell 95: 29-39, 1998.

25. Stiles B, Groszer M, Wang S, Jiao J and Wu H: PTENless means more. Dev Biol 273: 175-184, 2004.

26. Mocanu MM and Yellon DM: PTEN, the Achilles' heel of myocardial ischaemia/reperfusion injury? Br J Pharmacol 150: 833-838, 2007

27. Schwartzbauer G and Robbins J: The tumor suppressor gene PTEN can regulate cardiac hypertrophy and survival. J Biol Chem 276: 35786-35793, 2001

28. Wu DN, Pei DS, Wang Q and Zhang GY: Down-regulation of PTEN by sodium orthovanadate inhibits ASK1 activation via PI3-K/Akt during cerebral ischemia in rat hippocampus. Neurosci Lett 404: 98-102, 2006.

29. Hescheler J, Meyer R, Plant S, Krautwurst D, Rosenthal W and Schultz G: Morphological, biochemical, and electrophysiological characterization of a clonal cell (H9c2) line from rat heart. Circ Res 69: 1476-1486, 1991

30. L'Ecuyer T, Allebban Z, Thomas R and Vander Heide R: Glutathione S-transferase overexpression protects against anthracycline-induced H9c2 cell death. Am J Physiol Heart Circ Physiol 286: H2057-H2064, 2004.

31. Kim MJ, Moon CH, Kim MY, et al: KR-32570, a novel $\mathrm{Na}^{+} / \mathrm{H}^{+}$ exchanger-1 inhibitor, attenuates hypoxia-induced cell death through inhibition of intracellular $\mathrm{Ca}^{2+}$ overload and mitochondrial death pathway in H9c2 cells. Eur J Pharmacol 525: 1-7, 2005 .

32. Sheng R, Gu ZL, Xie ML, Zhou WX and Guo CY: Epigallocatechin gallate protects $\mathrm{H} 9 \mathrm{c} 2$ cardiomyoblasts against hydrogen dioxides-induced apoptosis and telomere attrition. Eur J Pharmacol 641: 199-206, 2010

33. Bordoni A, Hrelia S, Angeloni C, Giordano E, Guarnieri C, Caldarera CM and Biagi PL: Green tea protection of hypoxia/ reoxygenation injury in cultured cardiac cells. J Nutr Biochem 13: 103-111, 2002
34. Woo AY, Cheng $\mathrm{CH}$ and Waye MM: Baicalein protects rat cardiomyocytes from hypoxia/reoxygenation damage via a prooxidant mechanism. Cardiovasc Res 65: 244-253, 2005.

35. Park C, So HS, Shin $\mathrm{CH}$, et al: Quercetin protects the hydrogen peroxide-induced apoptosis via inhibition of mitochondrial dysfuntion in $\mathrm{H} 9 \mathrm{c} 2$ cardiomyoblast cells. Biochem Pharmacol 66 : $1287-1295,2003$

36. Jeong JJ, Ha YM, Jin YC, et al: Rutin from Lonicera japonica inhibits myocardial ischemia/reperfusion-induced apoptosis in vivo and protects $\mathrm{H} 9 \mathrm{c} 2$ cells against hydrogen peroxide-mediated injury via ERK1/2 and PI3K/Akt signals in vitro. Food Chem Toxicol 47: 1569-1576, 2009.

37. Chou HC, Chen YW, Lee TR, et al: Proteomics study of oxidative stress and Src kinase inhibition in $\mathrm{H} 9 \mathrm{c} 2$ cardiomyocytes: a cell model of heart ischemia-reperfusion injury and treatment. Free Radic Biol Med 49: 96-108, 2010.

38. Ihara Y, Urata Y, Goto S and Kondo T: Role of calreticulin in the sensitivity of myocardiac $\mathrm{H} 9 \mathrm{c} 2$ cells to oxidative stress caused by hydrogen peroxide. Am J Physiol Cell Physiol 290: C208-C221, 2006.

39. Witting PK, Liao WQ, Matthew JH and Neuzil J: Expression of human myoglobin in H9c2 cells enhances toxicity to added hydrogen peroxide. Biochem Biophys Res Commun 348: 485-493, 2006

40. Zhang XQ and Eyzaguirre C: Effects of hypoxia induced by $\mathrm{Na}_{2} \mathrm{~S}_{2} \mathrm{O}_{4}$ on intracellular calcium and resting potential of mouse glomus cells. Brain Res 818: 118-126, 1999.

41. Li D, Tomson K, Yang B, Mehta P, Croker BP and Mehta JL: Modulation of constitutive nitric oxide synthase, bcl-2 and Fas expression in cultured human coronary endothelial cells exposed to anoxia-reoxygenation and angiotensin II: role of AT1 receptor activation. Cardiovasc Res 41: 109-115, 1999.

42. Paller MS and Neumann TV: Reactive oxygen species and rat renal epithelial cells during hypoxia and reoxygenation. Kidney Int 40: 1041-1049, 1991

43. Kako K, Kato M, Matsuoka T and Mustapha A: Depression of membrane-bound $\mathrm{Na}^{+}-\mathrm{K}^{+}$-ATPase activity induced by free radicals and by ischemia of kidney. Am J Physiol 254: C330-C337, 1988.

44. Ratych RE, Chuknyiska RS and Bulkley GB: The primary localization of free radical generation after anoxia/reoxygenation in isolated endothelial cells. Surgery 102: 122-131, 1987.

45. von Harsdorf R, Li PF and Dietz R: Signaling pathways in reactive oxygen species-induced cardiomyocyte apoptosis. Circulation 99: 2934-2941, 1999.

46. Leslie NR, Bennett D, Lindsay YE, Stewart H, Gray A and Downes CP: Redox regulation of PI 3-kinase signalling via inactivation of PTEN. EMBO J 22: 5501-5510, 2003. 